\title{
Latvijas un Krievijas 1998. gada attiecību krīze: cēloṇi un norise
}

\author{
Crisis in Latvian-Russian Relations in 1998: \\ Causes and Progress
}

Eginhards Volāns, Mg. hist.

Latvijas Universitātes Vēstures un filozofijas fakultāte

Aspazijas bulvāris 5, Rīga, LV-1050

E-pasts: eginhards.volans@gmail.com

Raksts ir veltìts 1998. gada Latvijas un Krievijas attiecību krīzei un tās priekšvēstnešiem 1997. gadā. Pētỉjumā secīgi izklāstīti un izpētīti attiecību krīzes galvenie cēloṇi un norise, kā arī sniegts ieskats Latvijas, Krievijas un Rietumvalstu perspektīvā par attiecīgajiem notikumiem. Raksta galvenā avotu bāze ir periodika latviešu un krievu valodā, kā arī zinātniskā literatūra par šo tēmu. Darba pamattekstu veido trīs nodalas, no tām pirmā ir veltìta Latvijas un Krievijas attiecību eskalācijai no 1997. gada marta līdz 1998. gada februārim, otrā - krīzes norisei un izpausmēm no 1998. gada marta līdz aprīlim, trešā - krīzes deeskalācijai 1998. gada vasarā. Raksta tapšanas laikā secināts, ka Latvijas un Krievijas attiecību krīze, visticamāk, bija mākslīgi radīta no Maskavas puses, lai aizkavētu Latvijas eiroatlantisko integrāciju un novērstu Krievijas sabiedrības uzmanību no valstī briestošās iekšpolitiskās un ekonomiskās krīzes.

Atslēgvārdi: Latvijas un Krievijas attiecības, NATO paplašināšanās, Krievijas propaganda, Krievijas ietekmes aktivitātes, Krievijas tautieši.

The article is dedicated to the crisis in Latvian-Russian relations during the spring of 1998, as well as the related developments and preconditions, which already emerged during the 1997 . The author of the article has formulated and discussed the main reasons of the crisis, as well as researched the unfolding of the crisis, yielding insights from the perspective of Latvia, the West and Russian Federation. Latvian and Russian language press, as well as the related scientific literature have been considered as the main sources by the author. The article consists of three main chapters. The first one characterises the gradual escalation of the crisis in Latvian-Russian relations during the period from March 1997 to February 1998, the second chapter explores the development and manifestation of the crisis in 1998 from March to April, whilst the third chapter views the de-escalation of the crisis during the summer of 1998. The research brought a conclusion that the crisis in Latvian-Russian relations was most likely intentionally 
created by the Kremlin in order to slow down the Euro-Atlantic integration process of Latvia, as well as to divert the Russian society's attention from the emerging domestic and economic crisis.

Keywords: Latvian-Russian relations, NATO enlargement, Russian propaganda, Russian influence activities, Russian compatriots.

\section{levads}

Pēc Krievijas agresijas Ukrainā starp Maskavu un Rīgu ir iestājies, iespējams, ilgākais līdz šim pieredzētais atsaluma periods, kā rezultātā abu valstu attiecības ir sasniegušas vienu no vēsturiski zemākajiem punktiem. Turpinoties Maskavas nedraudzīgajai ārpolitikai, tādas tās, visticamāk, saglabāsies arī paredzamā nākotnē. Pēdējo gadu tendences liecina, ka ar Krievijas agresīvo ārpolitiku aizvien biežāk nākas saskarties arī Rietumvalstīm, no kurām daḷa pirms tam nereti iestājās par attiecību normalizāciju ar Maskavu. Pašlaik mūsdienu Krievijas ārpolitiku attiecībā pret Rietumiem vislabāk var raksturot kā virkni slēptu un destruktīvu ietekmes aktivitāšu, kuras nereti tiek definētas, izmantojot terminu "hibrīdkarš". Lai gan Rietumu sabiedriskajā domā "hibrīdkaru" mēdz aprakstìt kā salīdzinoši jaunu metodi, ar kuras palīdzību valstis cenšas palielināt savu geopolitisko ietekmi, postpadomju pieredzē tā drīzāk ir vērtējama kā daḷa no ierastās Maskavas ārpolitikas prakses.

Vēl jo vairāk - 1998. gada pavasarī Latvijas valdībai bija iespēja izbaudìt šāda veida ārpolitikas praksi visā tās krāšņumā. 1998. gada Latvijas un Krievijas attiecību krīzes laikā Latvija guva vērtīgu pieredzi, kā pareizi rīkoties, saskaroties ar Krievijas ietekmes aktivitātēm, kā tās vērtēt un kā tām atbildēt. Ar Latvijas pieredzes stāstu būtu vērts iepazīties arī citām Eiropas valstīm, kuras tikai tagad ir sākušas skaḷi runāt par Krievijas radītajiem draudiem.

Šì raksta mērḳis ir sniegt logisku un vispusīgu Latvijas un Krievijas 1998. gada krīzes un pirmskrīzes posma notikumu izklāstu, iezīmējot un analizējot Latvijas, Krievijas un Rietumvalstu darbības un reakciju uz attiecīgajiem notikumiem. Darbā izmantota vēstures genēzes jeb aprakstošā metode, ar kuras palīdzību ir rekonstruētas krīzes galvenās vēsturiskās cēlonssakarības. Pētījumā īpaša uzmanība veltīta tam, lai attēlotu ne tikai Latvijas, bet arī Krievijas un Rietumvalstu perspektīvu krīzes kontekstā, kā arī aplūkotas krīzes izpausmes Latvijas sabiedrībā, kuras varēja radīt potenciālus draudus valsts drošībai. Raksta pamatā ir periodikas avoti latviešu un krievu valodā, kuri aktīvi vēstīja par tālaika notikumiem. Papildus tam kā īpaši uzteicami informācijas avoti jāmin arī tēmai veltītie laikabiedru Žanetas Ozolin,as un Aivara Strangas zinātniskie darbi.

Kaut arī 1998. gada Latvijas un Krievijas attiecību krīze ir vērtējama kā nozīmīgs notikums mūsdienu Latvijas vēsturē, kopumā vēsturnieku un politologu darbos tā apskatīta maz. Jaunākie krīzei veltītie pētījumi datējami ar jaunās tūkstošgades sākumu, un to vērtējumos trūkst mūsdienu perspektīvas.

\section{Latvijas un Krievijas attiecību krīzes priekšvēstneši}

90. gadu vidū pēc Krievijas armijas izvešanas Rīgas un Maskavas attiecībās bija iestājies relatīva miera periods, kurā dominēja primāri ekonomiskās intereses. ${ }^{1}$ Latvijas eiroatlantiskās integrācijas procesi bija nosacīti apstājušies un neradīja tiešus draudus Maskavai, kas savukārt pēc Jevgenija Primakova (Evgenij Primakov) stāšanās ārlietu ministra amatā bija pievērsusies daudzvektoru ārpolitikas īstenošanai 
un škietami aizmirsusi par savām interesēm Baltijā. Tā, protams, bija tikai monētas redzamā puse, un Latvija ne tuvu nebija nozudusi no Maskavas lēmumu pieṇēmēju redzesloka.

1997. gada sākumā Maskavas ārpolitikas aktivitātes liecināja, ka Kremlis ir sācis izstrādāt jaunu stratēg̣iju attiecībā pret Baltijas valstīm - Maskavas primārais mērķis bija kavēt to integrāciju NATO. Krievijas lēmumu pieṇēmēji, visticamāk, juta, ka attiecības starp ASV un Baltijas valstīm ir sākušas "uzsilt" un pēdējo uzn,emšana Ziemel̦atlantijas līguma organizācijā varētu pienākt ātrāk, nekā paredzēts pirms tam. Rezultātā Maskava nolēma rīkoties, lai bez cīnas neatdotu tai stratēgiski svarīgās pozīcijas Baltijā.

Kremḷa plāni palielināt spiedienu pret Baltijas valstīm pirmo reizi izgaismojās ASV un Krievijas samita laikā Helsinkos. Maskava bija nolēmusi to izmantot kā platformu, lai aktualizētu tai svarīgus ārpolitiskus jautājumus, tostarp par Baltijas valstu geopolitisko orientāciju. Samita laikā Krievijas prezidents Boriss Jeḷcins (Boris El'cin) pirmo reizi publiski ierunājās par sava veida drošības garantiju piedāvāšanu Latvijai, Lietuvai un Igaunijai. Drošîbas garantijas tika prezentētas kā reǵiona "pozitīva kontrole"3 no Maskavas puses. Tās ietvaros Krievija solīja samazināt savu militāro klātbūtni reǵionā apmaiņā pret NATO paplašināšanas apturēšanu. Maskavas ieskatos Baltijas valstīm bija jākḷūst par vāji militarizētu buferzonu starp NATO un Krieviju.

Baltijas valstis vēl pirms samita sākuma bija manāmi satraukušās par iespējamo ietekmes pārdali reǵionā. Uz ASV un Krievijas sarunām īpaši asi reaǵēja Latvija, kuras Ministru prezidents Valdis Birkavs bažīgi secināja, ka Latviju joprojām vajā "Jaltas rēgs". ${ }^{4}$ Baltijas valstu satraukums bija pamatots - vēlāk noskaidrojās, ka papildus publiski piedāvātajām drošības garantijām B. Jeḷcins, sekojot "labākajai" padomju laiku praksei, aizkulišu sarunās bija piedāvājis ASV prezidentam Bilam Klintonam (Bill Clinton) noslēgt nerakstītu vienošanos, kurā B. Klintons apsolìtu neuzn,emt Baltijas valstis NATO. ${ }^{5}$ Kaut arī Maskava izrādīja iniciatīvu, Vašingtonas reakcija bija vēsa. Nekas neliecināja, ka ASV būtu gatavas atkāpties no plāniem nostiprināt savu ietekmi Baltijas jūras regíonā. Rezultātā pēc Helsinku samita Kremlis bija nonācis pie atziņas, ka ir iedzīts strupceḷā un vairs nav spējīgs runāt vienā līmenī ar ASV par ietekmi Baltijas valstīs. ${ }^{6}$

Pēc Helsinku samita gan bija vērojams de facto atsalums NATO un Krievijas attiecībās, tomēr 27. maijā abas puses parakstīja Divpusējo attiecību, sadarbības un drošǐbas dibināšanas aktu. Tas izsauca vērā ņemamu Krievijas konservatīvi orientētās elites kritiku. Piemēram, ietekmīgais politologs, Krievijas Ārpolitikas un drošības padomes vadītājs Sergejs Karaganovs (Sergej Karaganov) uzstāja, ka Maskavai jānovilcina akta parakstǐšana vismaz līdz NATO Madrides samitam jūlijā, kad Kremlis varētu gūt apstiprinājumu, ka alianse neplāno paplašināties uz bijušo postpadomju valstu rēķina. ${ }^{7}$ Savukārt PSRS ārlietu ministra Vjačeslava Molotova (Vjacheslav Molotov) mazdēls, Krievijas Valsts domes (VD) deputāts Vjačeslavs N̦ikonovs (Vjacheslav Nikonov), minēto līgumu uzskatīja par tik neizdevīgu Krievijai, ka pat salīdzināja ar Vācijai uzspiesto 1919. gada Versaḷas līgumu. ${ }^{8}$ Maskavai neizdevīgā dokumenta parakstī̌sana lika vēl vairāk apzināties, ka tai sāk trūkt reālu ietekmes sviru, lai aizkavētu Baltijas valstu iestāšanos NATO.

To apstiprināja arī jūlijā aizvadītais Madrides samits, kurā NATO pauda atbalstu Polijas, Čehijas un Ungārijas uzaicināšanai piedalīties aliansē, kā arī neoficiāli lika noprast, ka šì nebūs pēdējā alianses paplašināšanās kārta. ${ }^{9}$ Samita deklarācija bija skaidrs mājiens Kremlim, ka Baltijas 
valstis agrāk vai vēlāk tiks uzņemtas NATO. Samitā paustā retorika bija katalizators Maskavas pieaugošajam aizvainojumam pret NATO ambīijā̄m Austrumeiropā. Krievija bija nonākusi pie slēdziena, ka Baltijas valstu jautājumu vairs nevar atrisināt multilaterālā ceḷā un Maskavas attiecības ar baltiešiem turpmāk ir jāveido aci pret aci.

\section{Krievijas piedāvātās drošības garantijas}

5.-6. septembrī Viḷnāa tika aizvadīts Austrumeiropas valstu samits "Nāciju līdzāspastāvēšana un labas kaimin, attiecības", tajā valdošā retorika no Krievijas amatpersonu puses liecināja, ka Maskava, neņemot vērā sakāvi Madridē, ir apṇēmusies atkārtoti mēǵināt aizkavēt Baltijas valstu eiroatlantiskās integrācijas procesu. Piemēram, īsi pirms ierašanās Viḷnā Krievijas premjerministrs Viktors Černomirdins (Viktor Chernomyrdin) bija publiski paziņojis, ka Krievija iebilst pret Baltijas uznememšanu $N A T O,{ }^{10}$ savukārt samita laikā viņš atkārtoja iepriekš Helsinkos izskanējušo ideju par drošības garantijām. ${ }^{11}$ Vēl jo vairāk, Krievijas nodomus pretdarboties alianses ekspansijai reǵionā apstiprināja arī aizsardzības ministra Igora Sergejeva (Igor' Sergeev) pazinojumi, ka Krievija ir gatava palielināt savu militāro klātbūtni Kalininingradas apgabalā saistībā ar NATO aktivitātēm reǵionā. ${ }^{12}$

Baltijas valstu, sevišķi Latvijas, reakcija uz pieaugošajām Krievijas ārpolitikas aktivitātēm ir vērtējama kā novēlota. Augustā Latvijā pie varas bija nākusi jauna valdība, ko vadīja Guntars Krasts, kurš pārstāvēja nacionālistu partiju "TB/ LNNK". Lai gan Maskavas neapmierinātība ar Latvijas jauno valdību bija viegli paredzama, G. Krasta vadītais Ministru kabinets izlikās to nemanām. Rezultātā jaunās valdības deklarācijā Krievija bija pieminēta vien divas reizes, turklāt uzsverot nepieciešamību "turpināt labu kaimiņattiecību veidošanu”. ${ }^{13}$ G. Krasta valdības pasīvā nostāja pret Krieviju saglabājās arī pēc Maskavas amatpersonu pazinojumiem Viḷnas samitā. Piemēram, intervijā Latvijas krievvalodīgajam laikrakstam SM G. Krasts maldinoši apgalvoja: B. Jeḷcina īstenotā atvērto durvju politika ir pierādījums tam, ka Krievijas ārpolitikā dominējošu lomu ir ieṇēmusi reālistiska, nevis ideologiska attieksme pret Baltijas valstīm. ${ }^{14}$ Latvijas valdības amatpersonu publiskie izteikumi liecināja, ka tai bija vāja izpratne par notikumiem Maskavā un tās plāniem attiecībā pret Baltiju. To ievēroja arī Kremlis, kas Latvijas izvairīgo un pasīvo retoriku, visticamāk, interpretēja kā vājumu un aicinājumu palielināt spiedienu.

Tajā pašā laikā Krievijas ārpolitikā aizvien vairāk nostiprinājās pret Baltiju un NATO vērsts redzējums, kas bija saistīts ar vairākām būtiskām izmaiṇām valsts varas gaiteņos. Piemēram, septembrī no amata Prezidenta administrācijā bija spiesti šķirties ilglaicīgie B. Jeḷcina līdzgaitnieki Levs Suhanovs (Lev Suhanov) un Georgijs Satarovs (Georgij Satarov), neilgi pirms tam amatus bija pametuši arī Aleksandrs L,ivšics (Aleksandr Livshic), Jurijs Baturins (Jurij Baturin), Viktors Iljušins (Viktor Iljushin) un Mihails Krasnovs (Mihail Krasnov). Minētās personas atbalstijja Krievijas tuvināšanos ar Rietumiem un noderēja kā pretsvars politiskajā elitē pieaugošajai konservatīvo spēku ietekmei. ${ }^{15}$ Kremḷa liberālā spārna vājums, kā arī B. Jeḷcina pieaugošās veselìbas problēmas bija par iemeslu tam, ka 1997. gada nogalē Krievijas ārpolitikas groži bija praktiski nonākuši pretrietumnieciski noskan,oto politiḳu un ierēdniecības rokās.

Krievijas konservatīvo politiķu perspektīva uzskatāmi atspoguḷojās zinātniskajā konferencē "Krievija un Centrāleiropa 
jaunos geopolitiskos apstākḷıs”, kas oktobra sākumā notika Maskavā. Uzstājoties konferencē, varai pietuvinātais akadēmiķis Oḷegs Bogomolovs (Oleg Bogomolov) norādijja, ka pasaulē ir "izjaukts starptautiskais līdzsvars", "visur notiek ASV iejaukšanās" un "Krievijas ārpolitika turpmāk ir jāveido, izrietot no šīm geopolitiskajām reālijām". Līdzīgās domās bija arī parlamenta priekšsēdētāja vietnieks Sergejs Baburins (Sergej Baburin), kurš asi kritizēja NATO "ekspansiju", arī norādot, ka tās patiesais mērḳis ir "pakḷaut" Austrumeiropas valstis un vājināt Krievijas ietekmi Eiropā. ${ }^{16}$

Oktobra beigās Krievija beidzot uzrunāja visas trīs Baltijas valstis ar oficiālu drošîbas garantiju piedāvājumu. ${ }^{17}$ Tas, visticamāk, vērtējams kā tieša Maskavas atbilde uz 14. oktobrī aizvadīto ASV un Baltijas valstu tikšanos, kuras laikā Vašingtona apsolīja, ka drīzumā varētu parakstīt ilgi gaidīto partnerības hartu. ${ }^{18}$ Lai gan šì bija jau trešā reize gada laikā, kad Krievija publiski izvirzija ideju par drošības garantijām Baltijas valstīm, tā pirmo reizi izskanēja tik nopietnā tonī un zināmā mērā nāca kā pārsteigums gan Baltijas valstīm, gan to Rietumu partneriem.

Vēsturnieka A. Strangas vērtējumā Krievijas drošības garantijām bija trīs mērkii:

- pirmkārt, pārbaudīt Rietumvalstu reakciju un pārliecināties, cik tālu tās ir gatavas iet, lai atbalstītu Baltijas valstis;

- otrkārt, mazināt Baltijas valstu vienotỉbu; ${ }^{19}$

- treškārt, radīt iekšpolitiskās diskusijas un nemieru Baltijas valstīs, aktualizējot ideju par sadarbību ar Maskavu. ${ }^{20}$

Latvijas reakcija uz drošības garantijām bija saasināta un zināmā mērā haotiska. Valsts prezidents Guntis Ulmanis jau 25. oktobrī uzreiz pēc garantiju piedāvāšanas Lietuvai, nesagaidot oficiālu Latvijas Ārlietu ministrijas (ĀM) iesniegumu, tās nekavējoties noraidīja. ${ }^{21}$ Vēl vairāk - prezidents Krievijas drošības garantijas bija nievājoši nodēvējis par vienkāršu "papīra gabalu". ${ }^{22}$

Pret garantijām negatīvi noskaņoti bija arī citi Latvijas sabiedriskās domas līderi. Piemēram, Latvijas Ārpolitikas institūta vadītājs Atis Lejiņš izcēla, ka to pieņemšana nozīmētu Latvijas atgriešanos Krievijas ietekmes sfērā. Savukārt Saeimas deputāts Aleksandrs Kiršteins bažijās, ka garantijās nav atrunāts rīcības plāns gadījumā, ja Krievija uzbruktu Latvijai. Ironiskā kārtā pret garantijām kritiski noskan,ots bija pat Kremlim tradicionāli draudzīgais bijušais Latvijas ārlietu ministrs Jānis Jurkāns, kurš uzsvēra, ka ar to pieņemšanu divpusējā formātā "Latvijai būtu par maz". ${ }^{23}$

A. Strangas vērtējumā Rīgas asā reakcija pret drošības garantijām bija saistīta ar to, ka tās nerespektēja Latvijas viedokli, kā arī bija noformulētas pakta formā, kam Baltijas valstīs bija īpaši negatīva vēsturiskā konotācija. ${ }^{24}$ Vēsturiskās perspektīvas nozīmi izcēlusi arī politoloǵe Ž. Ozoliṇa, kuras vērtējumā baltiešu negatīvo attieksmi pret drošības garantijām ietekmēja arī Vācijas sākotnējais lēmums tās atbalstīt. ${ }^{25}$ Rezultātā Latvijas sabiedriskā doma nevil,us vilka paralēles starp Krievijas drošības garantijām 1997. gada rudenī un PSRS uzspiesto bāzu līgumu 1939. gada rudenī.

Lai gan starp politikiiem un sabiedrību valdīja vienprātība drošības garantiju vērtējumā, Baltijas valstis kavējās ar to oficiālu noraidīšanu. Lietuva to izdarīja 1. novembrī, Igaunija 2. novembrī, Latvija tikai 4. novembrī. ${ }^{26}$ Galu galā 8. novembrī Baltijas valstu ārlietu ministri nāca klajā ar kopīgu paziņojumu, ka noraida jebkāda veida divpusējās drošības garantijas no Krievijas puses. ${ }^{27}$

Lai gan Baltijas valstu lēmums vienoties kopīgā drošǐbas garantiju noraidīšanā ir vērtējams kā pozitīvs diplomātiskās prakses piemērs, tas nāca krietni par vēlu un liecināja, ka starp tām trūkst efektīvu 
sadarbības mehānismu. Īpaši vāja šajā laikā izskatījās Latvija, kuras darbībās atklājās arī vērā nnemamas starpresoru komunikācijas problēmas - atseviškas valsts augstākās amatpersonas bija at!̣āvušās komentēt Krievijas piedāvājumu bez saskaṇošanas ar ĀM. Tas radijja priekšstatu par Latvijas nespēju sekmīgi pārvarēt krīzes situācijas un liecināja par valdības vājajām diplomātijas spējām.

Tā kā Krievijas puse, visticamāk, necerēja, ka Baltijas valstis vai vismaz kāda no tām patiešām varētu garantijas pieņemt, to galvenais adresāts bija Rietumvalstis. Līdz ar to Maskavas perspektīvā drošības garantiju piedāvājums bija vērtējams kā vairāk vai mazāk izdevies:

- baltiešu tūḷāšanās ar garantiju noraidīšanu un savstarpējās komunikācijas trūkums radīja priekšstatu par to vienotības iluzoriskumu;

- Latvijas valdības haotiskā reakcija, atbildot uz garantijām, liecināja, ka tā nav gatava darbam sarežgìitās situācijās;

- Latvijas diplomātiskā takta trūkums, atbildot uz garantijām, pavēra durvis tās diskreditācijai Rietumu partneru vidū, prezentējot Krieviju kā labu attiecību iniciatoru;

- Rietumvalstu ieturētā reakcija lika domāt par to solidaritātes trūkumu attiecībā uz Baltijas valstīm.

Tikmēr pašas Krievijas reakcija uz drošības garantiju noraidī̌̌anu bija divējāda. No vienas puses, pragmatiskāk noskan,otie elites pārstāvji saprata, ka garantijām nebija reāla svara reǵiona drošības politikas darba kārtībā. Piemēram, Krievijas VD debatēs drošības garantijas tika pieminētas vien garāmejot, par galveno problēmu Latvijas un Krievijas attiecībās atzīstot sasāpējušo tautiešu jautājumu. ${ }^{28}$ No otras puses, radikālāk noskaņotā elites daḷa garantiju noraidīšanu uztvēra ar tai ierasto histēriju, piemēram, Liberāldemokrātu partijas līderis Vladimirs Žirinovskis (Vladimir Zhirinovskij) asi kritizēja Baltiju, minot, ka "Baltijas valstu valdības uzvedas bezkaunīgi”. Odiozais politikisis spekulēja, ka drošības garantiju noraidīšanai būs tālejošas sekas: 2000. gadā Krievijas teritorija būs sarukusi līdz 15. gadsimta izmēriem; Krievijas Tālie Austrumi piederēs kīniešiem un japāṇiem, bet Kaukāzā būs sācies jauns karš. Pēc V. Žirinovska domām, tas bija ASV prezidenta B. Klintona plāns Krievijas pilnīgai sagrāvei. ${ }^{29}$

\section{Latvijas un Krievijas attiecību eskalācija pēc drošǐbas garantiju noraidīšanas}

Decembra sākumā Krievijas prezidents B. Jeḷcins viesojās Zviedrijā, kur, uzrunājot parlamentu, negaidīti paziņoja, ka Krievija līdz 1999. gada 1. janvārim ir gatava par $40 \%$ samazināt savu bruṇoto spēku klātbūtni valsts ziemeḷietumos, un mudināja līdzīgi rīkoties arī citas reǵiona valstis. ${ }^{30}$ Kārtējo prezidenta B. Jeḷcina ekscesu Baltijas reǵiona virzienā nekavējoties izlaboja ārlietu ministrs J. Primakovs, kurš bija spiests precizēt, ka, neņemot vērā Maskavas vēlmi sadarboties ar tās Rietumu partneriem, tā joprojām stingri iebilst pret NATO ienākšanu reǵionā. ${ }^{31}$

Krievijas prezidenta pazinojumi Stokholmā kārtējo reizi apstiprināja aizdomas par Krievijā briestošo iekšējo nestabilitāti. Šajā laikā Krievijā bija aktualizējies jautājums par ietekmīgā liberālā reformatora Anatolija Čubaisa (Anatolij Chubajs) iespējamo atstādināšanu no pirmā vicepremjera amata. ${ }^{32}$ Tāpat neskaidrības saistībā ar Krievijas nākotni radīja bažas par B. Jeḷcina veselības stāvokli, kas strauji pasliktinājās. ${ }^{33}$ Vēl jo vairāk, uz iekšpolitisko intrigu fona valstī turpināja strauji pasliktināties arī ekonomiskā situācija. ${ }^{34}$ Nemot vērā visus iepriekš minētos faktorus, bija 
skaidrs, ka šādos apstākḷlos Maskava drīz vairs nebūs spējīga īstenot konsekventu, uz ilgtermiṇu vērstu ārpolitiku.

1997. gada izskaṇā Krievijas iekšējās problēmas zināmā mērā nāca par labu Baltijas valstīm, kas pēc drošības garantiju noraidīšanas varēja turpināt sekmīgu eiroatlantiskās integrācijas procesu bez bažām par tiešu Maskavas iejaukšanos. Rezultātā 13. decembrī Latvija beidzot saṇēma uzaicinājumu no Briseles uzsākt sarunas par iestāšanos Eiropas Savienībā (ES). ${ }^{35}$ Savukārt nākamā gada 16. janvārī Baltijas valstu prezidenti Vašingtonā parakstīja ilgi gaidīto Partnerības hartu ar ASV. ${ }^{36}$

Krievijas perspektīvā hartai tikai atvēlēta noteicošā loma reǵiona nākotnes veidošanā. Rezultātā jaunais gads tika iesākts ar agresīvu retoriku no Krievijas diplomātu puses, kas jau bija kḷuvusi par tradīciju. Piemēram, Krievijas ārlietu ministrs J. Primakovs vēl pirms hartas parakstīšanas bija skaidri pateicis, ka Maskava to atzīs tikai tādā gadījumā, ja tā pilnvērtīgi spēs aizstāt baltiešu dalību NATO. ${ }^{37}$ Lìgumam asus vārdus veltīja arī J. Primakova vietnieks Aleksandrs Avdejevs (Aleksandr Avdeev), kurš paziņoja, ka tas izjauks drošîbas līdzsvaru ne tikai Baltijā, bet visā Eiropā. ${ }^{38}$ Savukārt Krievijas ĀM pēc hartas parakstǐšanas demonstratīvi pazinoja, ka PSRS nekad nav okupējusi Baltijas valstis. ${ }^{39}$ Maskavas asā publiskā retorika bija mājiens, ka, neņemot vērā iekšpolitisko vājumu, tā tomēr negrasās samierināties ar Baltijas valstu nonākšanu ASV ietekmes sfērā.

Rezultātā 1998. gada sākumā vairāki indikatori liecināja, ka pēc hartas parakstīšanas Maskava varētu būt sākusi palielināt pret Latviju izdarīto spiedienu. Par to liecināja tas, ka, piemēram, Simona Vīzentāla centrs bija vērsies pie ASV prezidenta B. Klintona, lai apvainotu Latviju nacisma reabilitācijā. ${ }^{40}$ Tajā pašā laikā vairākas Latvijas krievu kopienas organizācijas bija nosūtījušas Krievijas premjerministram V. Černomirdinam vēstuli, kurā apvainoja Latvijas valdību krievu minoritātes tiesību pārkāpšanā. ${ }^{41}$ Bez tam Latvijas mediji ziņoja, ka valstī ieradusies Maskavas sociologu grupa, kas Krievijas valdības uzdevumā pētīja iedzīvotāju attieksmi pret politiskajiem, ekonomiskajiem un sociālajiem procesiem. ${ }^{42}$ Sociolog̣iskās aptaujas bija veiktas visās lielākajās Latvijas pilsētās, turklāt, kā noskaidrojās vēlāk, pētnieki bija melojuši un sākotnēji uzdevušies par Francijas sociologisko pētījumu centra pārstāvjiem. ${ }^{43}$ Krievijas intereses palielināšanos pamanīja arī Latvijas parlamentārieši. Piemēram, deputāts Guntis Eniņš vienā no Saeimas sēdēm bažīgi secināja, ka Latvijas krievu kopienas spiediens pret Latvijas valsti ir kluvis "pamatīgs un pietiekami briesmīgs", kā arī mudināja kolēguus būt uzmanīgiem un korektiem, izstrādājot iecerētos labojumus nepilsoṇu likumā. ${ }^{44}$ Lai gan atbildīgās institūcijas šos un citus indikatorus komentēja izvairīgi, bija skaidrs, ka Latvija atkal ir nonākusi Krievijas uzmanības centrā.

Vēl vairāk saspīlējumu abu pušu attiecībās palielināja Latvijas lēmums publiski atbalstīt ASV pozīcijas Irākas krīzē. Tuvo Austrumu jautājumā Maskava bija gājusi pat tik tālu, ka apvainoja Vašingtonu centienos izraisīt Trešo pasaules karu. ${ }^{45}$ Rezultātā prezidenta G. Ulmaņa februārī paustā apṇēmība atbalstīt ASV armiju un nosūtīt uz Irāku līdz 15 militārpersonām ${ }^{46}$ Kremḷa perspektīvā tika interpretēta kā nedraudzīga un pat atklāti provokatīva.

\section{Latvijas un Krievijas attiecību krīze}

Par 1998. gada Latvijas un Krievijas attiecību krīzes katalizatoru ir pien,emts uzskatīt 3. martā aizvadīto nesankcionēto mītinu pie Rìgas Domes (RD). Mìtiņa 
iegansts bija iepriekšējā dienā laikrakstā Panorama Latvii publicētais žurnālistes Innas Harlanovas raksts par komunālo maksājumu celšanu, kam bija pievienots aicinājums lasītājiem pulcēties protesta akcijā. ${ }^{47}$ Publikācijas iespaidā uz mītinu bija ieradušies aptuveni 1000 krievvalodīgie seniori. Saasinoties protestētāju retorikai, daḷa sanākušo izgāja uz Krišjāṇa Valdemāra ielas braucamās daḷas un uz 45 minūtēm paralizēja satiksmi. ${ }^{48}$ Kaut arī varas iestādes centās izveidot dialogu, policistu lūgumi atbrīvot brauktuvi netika uzklausīti, kā rezultātā mìtiņš tika izgaiṇāts ar spēku. ${ }^{49}$

Protesta akcijas izgain̄āšana sākotnēji izpelnījās vietējo mediju otršķirīgu uzmanību un tika vērtēta kā pamanāms, taču salīdzinoši maznozīmīgs incidents. Piemēram, valsts populārākajā laikrakstā "Diena" tas pieminēts tikai 3. lappusē, savukārt "NRA" un "Lauku Avīzē" tam atvēlēta daḷa no 2. lappuses. Pavisam cita situācija vērojama krievvalodīgajos medijos, kur protesta akcijai tika pievērsta pārspīlēti liela uzmanība un tā tika atspoguḷota izteikti emocionālā tonī. Latvijas lielākajos krieviski rakstošajos laikrakstos $S M$, Chas un Panorama Latvii mītiņš atspoguḷots titullapā, turklāt rakstu saturs bija izteikti naidīgs Latvijas valstij. Arī Krievijas mediji it kā mazsvarīgo protesta akciju atspogul,oja plašās detaḷās. Vēsturnieks A. Stranga min, ka jau nākamajā dienā tai uzmanību pievērsa mediji, kuri pieder Krievijas oligarhiem Borisam Berezovskim (Boris Berezovskij) un Vladimiram Gusinskim (Vladimir Gusinskij). ${ }^{50}$ İpašu lomu marta sākumā ieņēma tieši Krievijas oligarhiem piederošie televīzijas kanāli, kas Latvijai veltīja vairākus naidīgi noskaņotus propagandas sižetus. ${ }^{51}$ Tajos tika rādīti videomateriāli ar piketa dalībnieku izgaiņāšanu un apgalvots, ka šādā veidā Latvijas varas iestādes vēršas pret vietējo krievvalodīgo minoritāti. Izteikti naidīgā un koordinētā propagandas kampaņa liecināja, ka tā varētu būt pasūtīta "no augšas". ${ }^{52}$

Jau 4. martā notikumus Latvijā komentēja arī Krievijas augstākās amatpersonas. Piemēram, ārlietu ministrs J. Primakovs protesta izgaiṇāšanu raksturoja kā "kliedzošu cilvēktiesību pārkāpumu”, Latvijas policijas darbības nosauca par "pretīgām” un norādīja, ka pievērsīs šì jautājuma risināšanai arī Polijas ārlietu ministra Bronislava Geremeka (Bronislaw Geremek) uzmanību - viṇš tobrīd ieṇēma (Eiropas Drošības un sadarbības organizācijas (EDSO) priekšsēdētāja amatu. ${ }^{53}$ Ar paziņojumiem, kas vērsti pret Latviju, klajā nāca arī prezidenta preses sekretārs Sergejs Jastšembskis (Sergej Jastrzhembskij), kurš paziṇoja, ka B. Jeḷcins solidarizējas ar J. Primakovu, kā arī norādīja, ka tuvākajā laikā Krievijas un Latvijas prezidentu tikšanās vairs nebūs iespējama. ${ }^{54} 6$. martā Latvijas kritikai pievienojās arī premjerministrs V. Černomirdins, kurš nosodīja iepriekš izskanējušos Latvijas premjera G. Krasta izteikumus, ka pensionāru mītiņš pie RD varēja būt Krievijas provokācija. ${ }^{55}$

Tajā pašā laikā pret Latviju vērstās aktivitātēs sāka iesaistīties arī vairākas radikālas organizācijas, kurām it kā nebija sakara ar valdību. Piemēram, komunistu kustība "Darba Krievija” bija noorganizējusi mītinu pie Latvijas vēstniecības Maskavā. Organizācijas vadītājs Viktors Anpilovs (Viktor Anpilov) sanākušos bija mudinājis "radīt neizturamus apstākḷus Latvijas vēstniecības darbiniekiem", taču Krievijas varas iestādes protesta akcijas norisē neiejaucās. ${ }^{56}$ Lai gan kaimiņvalsts oficiālie avoti ziṇoja, ka pasākumā kopā piedalījās aptuveni 1500 personas, Latvijas vēstniecības pirmais sekretārs Vilmārs Heniņš savos aprēḳinos bija "nedaudz" pieticīgāks un telefonintervijā laikrakstam "Diena" norādīja, ka mītinu apmeklēja vien 15-20 personas un tas tika aizvadìts "tradicionālas demagogijas garā". ${ }^{57}$ 
Papildus tam Krievijas puse īstenoja virkni darbību, kas praktiski iesaldēja abu valstu sadarbību diplomātiskā līmenī. Piemēram, 6. martā tika atcelta VD priekšsēdētāja Genādija Seḷezņova (Gennadij Seleznjov) vizīte Latvijā. No ieplānotā Latvijas apmeklējuma atteicās arī Krievijas varas partija "Mūsu mājas - Krievija". Vēl vairāk - VD deputāti mudināja Krievijas prezidentu īstenot atbildes pasākumus pret Latviju. Maskavas varas kuluāros sāka klīst baumas par iespējamu ekonomisko sankciju ieviešanu. ${ }^{58}$ Rezultātā marta sākumā īsā laika posmā pret Latviju bija nostājušies praktiski visi lielākie aktori, kuri īstenoja Krievijas ārpolitiku. Tas iezīmēja pagrieziena punktu krīzes eskalācijā - kopš šì brī̌̌a bija skaidrs, ka abu valstu attiecību pasliktināšanās ir nevis nejaušība, bet gan mērk,tiecīga Maskavas politika.

8. martā prezidenta preses sekretārs S. Jastšembskis pirmo reizi publiski pazinoja, ka prezidenta ārpolitikas padomnieki iesaka ieviest pret Latviju tirdzniecības ierobežojumus. ${ }^{59}$ Sajūsmu par ekonomisko sankciju ieviešanu neslēpa Latvijas krievvalodīgā prese. Piemēram, laikraksts $S M$ zin,oja, ka Krievijas sankcijas būs vērstas pret Latvijas biznesa aprindām, kas "barojas" no Krievijas tranzìta un tomēr diskriminē krievu minoritāti. ${ }^{60}$ Krievvalodīgajā presē valdošā sajūsma par sankcijām bija indikators tam, ka liela daḷa Latvijas iedzīvotāju krīzes apstākḷos ir nostājušies kaiminvvalsts pusē. Tas radīja savstarpējas neuzticēšanās vilni Latvijas sabiedrībā un labvēlīgu augsni tālākai starpetniska konflikta eskalācijai, kas atbilda Maskavas interesēm.

Lai gan oficiāli sankcijas tā arī netika ieviestas, Kremlis lika lietā savus sakarus, lai de facto izdarītu spiedienu uz Latvijas ekonomiku. Tas tika panākts, izmantojot netiešus ietekmes instrumentus, piemēram, ārlietu ministra J. Primakova personīgos sakarus energētikas nozarē, Maskavas mēra Jurija Lužkova (Jurij Luzhkov) ietekmi biznesa aprindās un Kremlim pietuvinātus oligarhus, lai mudinātu uzṇēmumus pārtraukt sadarbību ar Latviju un boikotēt tās preces. ${ }^{61}$ Kaut arī ekonomiskās sankcijas bija acīmredzamas, Maskava, bažijoties par starptautiskās sabiedrības nosodījumu, to esamību vairākkārt noliedza.

Latvijas pusei neatlika nekas cits kā paust sašutumu un neizpratni par Krievijas lēmumu mērḳtiecīgi pasliktināt abu pušu attiecības. 5. martā Latvijas ĀM nāca klajā ar paziṇojumu, kurā mudināja Krievijas pusi pārstāt izteikt nepamatotus apvainojumus, savukārt iekšlietu resors, kas bija atbildīgs par 3. marta mìtina izgaiņāšanu, bija spiests atzīt, ka policija protestu apspiešanā izmantojusi stekus, taču tās darbību rezultātā nebija cietusi neviena persona. ${ }^{62} 6$. martā situāciju komentēja arī ārlietu ministrs V. Birkavs, kurš atzina, ka "pēdējo dienu notikumi ievelk melnu strīpu Latvijas un Krievijas attiecībās" un ka Maskava cenšas nomelnot Latviju. ${ }^{63}$ Reaǵējot uz Maskavas naidīgo propagandu, Latvijas ārlietu resors bija spiests uzsākt situācijas "skaidrošanas kampaṇu" Rietumvalstu un starptautisko organizāciju pārstāvju vidū. 9. martā ĀM oficiāli informēja EDSO, ASV un Eiropas Savienības valstu vēstniekus par aktualitātēm Latvijas attiecībās ar Krieviju. ${ }^{64}$

Pieaugot Krievijas spiedienam, Latvijas sabiedrībā izraisījās diskusija par iespējamiem krīzes orḳestrētājiem. Viens no sabiedrībā izplatītākajiem skaidrojumiem bija, ka krīzi ir izraisījusi Krievijas specdienestu iejaukšanās Latvijas iekšējās lietās. Ar šādu hipotēzi iepriekš bija atḷāvies spekulēt pat premjerministrs G. Krasts, taču Latvijas atbildīgie dienesti šãdu varbūtību neuztvēra nopietni. ${ }^{65}$ Par Krievijas specdienestu tiešu iejaukšanos trūka pierādījumu, turklāt šì naratīva tālāka attīstīšana oficiālā līmenī varēja radīt papildu spriedzi jau tā nestabilajās attiecībās ar Krieviju. Vēl viens sabiedrībā izplatīts krīzes skaidrojums tika 
saistīts ar 1997. gada nogalē no ieslodzījuma atbrīvoto bijušo Latvijas Komunistiskās partijas pirmo sekretāru Alfrēdu Rubiku. ${ }^{66}$ Politikis tika atbrīvots uz Oktobra revolūcijas 80. gadadienu, turklāt viṇa atbrīvošana notika neskaidros apstākl,os. ${ }^{67}$ A. Rubikam bija spēcīga ietekme laikrakstā Panorama Latvii, kas bija atbildīgs par 3. marta mītina organizēšanu - tas kḷuva par krīzes katalizatoru. ${ }^{68}$ Papildus tam A. Rubikam bija saglabājušies cieši politiskie sakari Krievijā. 1998. gada sākumā viņš ilgi viesojās Maskavā un tikās ar Maskavas mēru J. Lužkovu un Krievijas Komunistiskās partijas priekšsēdētāju Genādiju Zjuganovu (Genadij Zjuganov). ${ }^{69}$ Gan J. Lužkovs, gan G. Zjuganovs bija vieni no pirmajiem Krievijas politikiiem, kas mudināja Kremli vērsties pret Latviju, kā arī izcēlās ar l’oti asiem izteikumiem par Latviju, piemēram, J. Lužkovs bija salīdzinājis Latviju ar Pola Pota (Pol Pot) Kambodžu, ${ }^{70}$ savukārt G. Zjuganovs minējis, ka Latvijā norisinoties tas, kas nenotika pat aparteīda laikā Dienvidāfrikā. ${ }^{71}$

Papildus tam bažas radīja arī vairākas ar Krieviju saistītas radikāḷu organizācijas, kuras 1997. gada nogalē un 1998. gada sākumā bija aktivizējušās Latvijā. Piemēram, jau 1997. gada oktobrī Latvijas medijos parādījās informācija, ka Latvijā viesojies Krievijas labējo radikāḷu kustības "Krievu nacionālā vienotība" līderis Aleksandrs Barkašovs (Aleksandr Barkashov). ${ }^{72}$ Tāpat 1997. gada nogalē Latvijā slepeni it kā bija notikusi radikālā Krievijas politik̦a V. Žirinovska vadītās Liberāldemokrātu partijas spārna atklāšanas konference. ${ }^{73} \mathrm{~Pa}$ pildus tam šajā laika posmā bija aktivizējusies arī vietējā krievu kopiena - 1997. gada 9. oktobrī 17 organizācijas apvienojās un nodibināja jaunu biedrību "Krievu nacionālās kultūras autonomija". ${ }^{74}$ Vēl jo vairāk aizdomas radijja fakts, ka protesta akcijās 1998. gada pavasarī periodiski tika manīti arī nacionālboḷševiku partijas biedri.

\section{Leğionāru dienas faktors krīzes eskalācijā}

Par vienu no krīzes centrālajiem notikumiem kḷuva 16. marta leǵionāru dienas gājiens, kam īpašu uzmanību pievērsa vairāki Rietumvalstu mediji (piemēram, zviedru Expressen un Svenska Dagbladet, itālu Corriere della Sera, franču Le Figaro)..$^{75}$ Eiropas laikrakstos gājiens tika raksturots kā plaši apmeklēts, tā mērḳis esot holokausta noliegšana. ${ }^{76}$ Vairumā gadijjumu šāds leǵionāru dienas atspoguḷojums sakrita ar Krievijas propagandas interpretāciju. To apstiprina arī vēsturnieks A. Stranga, kura vērtējumā Rietumu un vietējās krievu preses reakcija uz 16. marta gājienu bija pārspīlēta un mākslīgi sakāpināta, jo, piemēram, 1997. gadā no 7000 Latvijā mītošajiem leǵionāriem uz pasākumu bija ieradušies tikai $250 .{ }^{77}$ Tomēr pirms 1998. gada gājiena ārvalstu medijos bija radīts tāds informatīvais fons, no kura varēja secināt, ka 16. marts ir teju vai viena no svarīgākajām piemiņas dienām Latvijā.

Kaut arī medijos bija sacelta ažiotāža, legionāru diena tika aizvadīta bez vērā n,emamiem starpgadījumiem. Par vienīgo incidentu parūpējās kāds krievvalodīgs pensionārs, kurš metās pūlī ar saukliem pret "fašismu" un pasākuma dalībniekus apmētāja ar burkānu šḳēlēm. Pensionāra līdzgaitnieki pamatā bija krievvalodīgi seniori, kurus pavadīja aptuveni 20 krieviski runājoši jaunieši. ${ }^{78}$

Rezultātā Latvijas pusei vislielākās galvassāpes radīja nevis iespējamās provokācijas no t. s. antifašistu puses, bet gan vairāku valsts amatpersonu dalība gājienā. Leǵionāru dienu, par spīti ārlietu un aizsardzības ministru aizliegumam, ${ }^{79}$ apmeklēja tādas augsta ranga amatpersonas kā Nacionālo brunoto spēku komandieris Juris Dalbiņš, armijas orḳestra vadītājs Dainis Uškāns, Jūras spēku komandieris Gaidis Zeibots, kā arī Saeimas deputāti Dzintars 
Ābiḳis, Oskars Grīgs, Pēteris Tabūns, Jānis Straume, Māris Kimenis un Aigars Jirgens. ${ }^{80}$

Latvijas amatpersonu attieksme pret dalību 16. marta pasākumos bija vērtējama kā vieglprātīga un ievērojami pasliktināja Latvijas pozīcijas konfliktā ar Maskavu. Vēsturnieks Uldis Neiburgs vēl pirms gājiena spekulēja, ka amatpersonas, iespējams, neapzinājās to, cik negatīvi legionāru gājiens ietekmēs Latvijas tēlu Rietumos, kā piemēru minot Satversmes aizsardzības biroja (SAB) direktora Laina Kamaldina nespēju objektīvi izvērtēt 16 . marta radītos riskus Latvijas tēlam ārzemēs. Neilgi pirms tam valsts galvenā specdienesta vadītājs kādā no intervijām bija minējis, ka 1998. gada gājiens ne ar ko neatškirsies no citiem gadiem, rezumējot: ja 15 večuku satiekas pie ugunskura un iedzer alinu - tad nekā nopietna tur nav. U. Neiburga vērtējumā ar vērā ṇemamām stratēǵiskās komunikācijas kḷūdām pirms gājiena bija izcēlies arī Valsts prezidenta padomnieks drošības jautājumos Guntars Zaḷaiskalns, kurš medijiem bija kḷūdaini apgalvojis: "G. Ulmanis neiebildìs pret to, ka Rìgā tiek plānota organizācijas Waffen SS 55 gadu jubileja". ${ }^{81}$

Augsta ranga valstsvīru piedalīšanās legionāru gājienā viennozīmīgi nāca par labu Krievijas centieniem diskreditēt Latviju Rietumvalstu vidū. Radīto reputācijas risku dēl prezidents 31. martā bija spiests izdot paziņojumu, kurā uzsvēra, ka Latvija ir demokrātiska valsts un tās amatpersonas nedrīkst piedalīties Waffen SS leg̣ionāru atceres pasākumos, savukārt komandieris J. Dalbiņš bija spiests atkāpties no ieņemamā amata. ${ }^{82}$

Kā jau bija paredzams, 16. marta gājienam sekoja asa Maskavas pretreakcija. Krievijas ĀM nāca klajā ar pazinojumu, ka Waffen SS leǵiona vēsture ir saistīta ar "tūkstošiem cilvēku asiṇu un ciešanām”, un apvainoja Latviju nacisma reabilitēšanā, ${ }^{83}$ savukārt Krievijas mediji izplatīja, iespējams, sagrozītu informāciju, ka 16. marta gājienu it kā īpaši asi nosodījuši arī Francijas prezidents Žaks Širaks (Jacques Chirac) un Vācijas kanclers Helmūts Kols (Helmut Kohl). ${ }^{84}$

Leǵionāru pieminas pasākumi atblāzmojās arī pašā Krievijā. 17. martā ar olām tika apmētāta Latvijas vēstniecība Maskavā. Sanākušie aicināja apcietināt Latvijas vēstnieku, savukārt vietējās varas iestādes kārtējo reizi ignorēja protestētāju radītos draudus vēstniecības darbiniekiem. Pasākumu kārtējo reizi organizēja kustība "Darba Krievija", kas pirms tam 9. martā pie konsulāta Pleskavā jau bija paspējusi sadedzināt Latvijas karogu, savukārt 13. martā, iespējams, draudējusi konsulātam ar teroraktu. ${ }^{85}$

Uzreiz pēc leğionāru dienas gājiena, 17. martā, Esplanādē tika aizvadīta krīzes laikā lielākā krievu kopienas protesta akcija. Tās oficiālais iemesls bija Latvijas valdības lēmums nepagarināt PSRS pasu derīguma termiṇu. Šis jautājums pamatā skāra Latvijas nepilsoṇus, no kuriem daudzi joprojām ikdienā izmantoja PSRS izdotās pases. Protesta akciju organizēja Kustība par sociālo taisnīgumu un līdztiesību Latvijā, tajā piedalījās arī politiskie spēki - Latvijas Sociālistiskā partija un Tautas Saskaņas partija. Kā ierasts, lielākā daḷa protestētāju bija krievvalodīgie pensionāri, kurus pavadīja neliela grupiņa jauniešu, kuri šoreiz sevi jau atklāti identificēja kā nacionālboḷševikus. Neṇemot vērā pasākuma masveidīgumu (Chas ziņoja, ka pasākumu apmeklēja 5000-7000 cilvēku, savukārt Panorama Latvii ${ }^{86}$ un $S M$ - līdz $10000^{87}$ ), tas aizritēja bez vērā ñemamiem starpgadījumiem. ${ }^{88}$ Vienīgā protesta akcijas daḷa, kas varēja pievērst uzmanību, bija nacionālboḷševiku klātbūtne. Kā novērojis laikraksts "Diena", nacionālbol̦ševiku aktīvisti šajā periodā bija klātesoši gandrīz katrā pret Latviju vērstajā mītiṇā Krievijā, turklāt pēdējos mēnešos to aktivitātes aizvien biežāk 
izgaismojās arī Latvijā, kur, pēc žurnālistu domām, mitinājās aptuveni 100 radikāḷu atbalstītāji. ${ }^{89}$

Paralēli plaši apmeklētiem mītiniem krīzes sākumposmā tika novērotas arī vairākas mazāka mēroga provokācijas, kuru mērkisis bija šķelt Latvijas sabiedrību. Piemēram, 10. martā prese ziņoja, ka ar nepiedienīgiem, pret latviešiem vērstiem saukliem esot apzīmēta 2. Rīgas pagarinātās dienas skola. Vandali netālu no skolas bija pakāruši kaki, pie kura piesprauduši uzrakstu, kurā draudēja izrēḳināties ar latviešiem. Par nodarījumu tika aizturēti četri krievu tautības jaunieši. Viens no tiem vēlāk atzinās, ka esot bijis nokaitināts, jo nelietīgie latvieši 3. martā situši pensionārus. ${ }^{90}$ Papildus tam neilgi pirms Leǵionāru dienas Latvijas mediju redzeslokā bija nonākušas pagrīdes organizācijas "Sarkanais koris" veidotas skrejlapas, kurās iedzīvotāji tika aicināti "pretoties sistēmai". ${ }^{91}$ Vēlāk skrejlapu saturs tika pārpublicēts arī pagrīdes laikrakstā General'naja Linija, kura izdevēji aicināja uz vardarbību pret buržujiem un tēlaini aprakstīja, kā līdz nāvei tiek nospārdīts valsts valodas inspektors. Kaut arī izdevumu saturs bija agresīvs un pretvalstisks, SAB direktora vietnieka Ulda Dzenīša vērtējumā tie draudus valsts drošỉbai neradīja. Vēl jo vairāk, pēc amatpersonas domām, Latvijai kā demokrātiskai valstij bija jāciena citādi domājošie iedzīvotāji. $^{92}$

Vēl viens protesta akciju vilnis notika Komunistiskā genocīda upuru piemiņas dienā 25. martā. Šoreiz mītiņos pie Krievijas diplomātiskajām pārstāvniecībām pulcējās latviski runājošā, nacionālistiski noskaņotā sabiedrības daḷ. Šiem mītiniem bija vēsturisks pamatojums, tomēr vietējā krievu prese tos interpretēja kā pierādījumu tam, ka Latvijas sabiedrībā valda nekontrolējams nacionālisms un rusofobija. Vietējais krievvalodīgais laikraksts $S M$ minēja, ka piketa dalībnieki ieradušies ar provokatīviem un cilvēkiem naidīgiem plakātiem, kas bijuši vērsti pret Latvijas krieviem. ${ }^{93}$ Savukārt Chas mìtinus aprakstīja kā "rusofobijas dienu", kurā piedalījās radikāl̦i un nacionālisti. ${ }^{94}$ Pasākumi aizritēja bez vērā ņemamām provokācijām, taču to laikā tika aizturētas divas personas, tostarp kāds jauns vīrietis, kas bija ar kāju iespēris vienai no piemiṇas brīža dalībniecēm. ${ }^{95}$

\section{Aprīịa spridzināšanas un citas provokācijas}

Kaut arī Krievijas un vietējie prokremliskie mediji centās dramatizēt situāciju Latvijā, 1998. gada martā netika novērots neviens vērā n,emams incidents, kas varētu noderēt kā iegansts tālākai krīzes eskalācijai. Situācija zināmā mērā mainījās 2. aprīlī, kad pie Rīgas sinagogas nogranda sprādziens. Tas bija katalizators jaunam no Krievijas orksestrētam propagandas vilnim, lai radìtu maldīgu priekšstatu par pieaugošiem terorisma draudiem Latvijā. Situāciju labāku nepadarīja arī tas, ka kopš 1995. gada šis bija jau trešais sprādziens, ko piedzīvoja Rīgas sinagoga. ${ }^{96}$

Sprādziens tika plaši atspogul,ots ne vien Krievijas, bet arī Rietumvalstu medijos. Krievijas propagandas mērkis bija sasaistīt sinagogas spridzināšanu ar marta notikumiem un Rietumvalstīs sliktu slavu ieguvušo leǵionāru gājienu. Neievērojot Krievijas centienus, Rietumvalstis bija mērenas savā vērtējumā un nesteidzās piekrist Maskavas propagandas naratīviem. Piemēram, ASV medijs Baltimore Sun skaidroja, ka situācija Latvijā ir neviennozīmīga un ir tieši saistīta ar valsts sarežǵito vēsturi un attiecībām ar Maskavu. ${ }^{97}$

Vēsturnieka A. Strangas vērtējumā Latvijas politiki apjauta, cik liels starptautisks skandāls var izvērsties, ja šī situācija netiks laikus atrisināta. ${ }^{98}$ Iespējams, tieši šì iemesla dēḷ Latvija nolēma nekavējoties 
lūgt ASV Federālā izmeklēšanas biroja palīdzību terorakta atklāšanā. ${ }^{99}$ Salīdzinājumā ar 3. marta mītiṇa izgaiṇāšanu Latvijas amatpersonu reakcija uz teroraktu un tā seku novēršana bija tūlītēja un konsekventa. Tika pieñemts lēmums nekavējoties veikt sinagogas remontu par Rīgas pašvaldības lìdzekḷiem, un apkārt sinagogai tika uzstādītas novērošanas kameras. ${ }^{100}$ Latvijas valdība publiski nosodīja teroraktu un steidzamības kārtā atstādināja no amata atbildīgo amatpersonu - Valsts policijas priekšnieku Aldi Lieljuksi. ${ }^{101}$ Galu galā Latvijas pusē nostājās arī sinagogas rabīns Natans Barkāns un Izraēlas vēstnieks Latvijā Odeds Ben-Hurs (Oded Ben-Hur), kurš bija spiests skaidrot, ka Latvijas sabiedrība nav antisemītiska un valstī neatdzimst fašisms. ${ }^{102}$

6. aprīlī Rìgu satricināja vēl viens sprādziens. Netālu no Krievijas vēstniecības ēkas uzsprāga kādā atkritumu tvertnē ievietota mīna. Lai gan sprādzienā nebija cietušo un tajā necieta vēstniecības ēka, provokācija pie Krievijas diplomātiskās pārstāvniecības izsauca kārtējo paniku prokremlisko mediju vidū. Laikraksts Chas sprādzienu aprakstīja kā pirmo starptautisko teroraktu Latvijas vēsturē ${ }^{-103}$ un spekulēja, ka sprādziens varētu negatīvi atsaukties uz Latvijas centieniem iestāties ES. ${ }^{104}$ Medijos radīto informatīvo fonu Rietumvalstis neṇēma vērā un sprādzienam nepievērsa īpašu uzmanību, apzinoties, ka tas neradīja reālus draudus vēstniecības darbiniekiem un, visticamāk, bija vērtējams kā sīka provokācija, lai pasliktinātu jau tā bēdīgā stāvoklī esošās Latvijas un Krievijas attiecības. Arī vēsturnieka A. Strangas vērtējumā abi minētie sprādzieni bija provokācijas, ar kuru palīdzību Maskavu atbalstošie radikāḷ centās mākslīgi saasināt situāciju Latvijā. ${ }^{105}$ Sagadīšanās pēc Krievijas vēstniecība jau krīzes sākumposmā bija nākusi klajā ar "pravietisku" brīdinājumu - tās rīcībā esot informācija, ka latviešu radikālās organizācijas plānojot veikt provokācijas pret kultūras un vēstures pieminekḷiem un Krievijas diplomātiskajām pārstāvniecībām. Vēstniecības ieskatā latviešu radikāḷi minētajās provokācijās plānoja nepamatoti apvainot Krieviju. ${ }^{106}$

Nākamajās dienās pēc spridzināšanām Rīgā krievvalodīgā prese aktīvi ziņoja par līdzīgām provokācijām arī citviet. Piemēram, 4. aprīlī Liepājā ar melnu krāsu tika apliets piemineklis holokausta upuriem. ${ }^{107}$ Laikraksts $S M$ ziņoja, ka reizē ar incidentu pie Krievijas vēstniecības sprādziens esot nograndis arī Valkas rajonā, netālu no Smiltenes. Lai gan trūka pierādījumu, krievu prese notikumu Vidzemes laukos interpretēja kā teroraktu un saistīja ar notikumiem galvaspilsētā. ${ }^{108} 8$. aprīlī krievu presē izplatījās ziņas, ka Rīgā kādā Valdeḳu ielas namā esot izkārts nacistiskās Vācijas karogs. Arī šai ziņai nepamatoti tika pievienota birka "terorisms". ${ }^{109} 11$. aprīlī spridzeklim līdzīgs priekšmets tika atrasts Rēzeknes naftas bāzē "Rēzna", savukārt policija bija saṇēmusi brīdinājumu par it kā Zaķusalas televīzijas tornī ievietotu bumbu. ${ }^{110}$

\section{Krīzes deeskalācija}

Aprīlī vērā ņemams saspīlējums bija iestājies arī Latvijas iekšpolitikā. Mēneša sākumā premjerministrs G. Krasts bija spiests atlaist Kremḷa biznesu lobējošās partijas "Saimnieks" ekonomikas ministru Ati Sausnīti saistībā ar panisko attieksmi pret Krievijas ieviestajām sankcijām. ${ }^{111}$ 8. aprīì̄ partija "Saimnieks", kuras kontrolē tobrīd bija četri ministru krēsli, paziņoja, ka izstājas no valdošās koalīcijas, tādā veidā draudot gāzt Latvijas valdību. Tiesa, neievērojot pamatīgu šūpošanos Saeimā, G. Krasts spēja konsolidēt ap sevi atlikušās koalīcijas partijas un noturēt varas grožus. ${ }^{112}$

Pēc nosacītas iekšpolitiskās krīzes pārvarēšanas par valsts galveno prioritāti kḷuva 
attiecību normalizēšana ar Krieviju un situācijas skaidrošana Rietumvalstu partneriem. G. Krasts krīzes radīto apstākḷu dēl atcēla ieplānoto vizīti uz ASV, savukārt prezidenta G. Ulmaņa vadībā tika izveidota darba grupa krīzes seku pārvarēšanai. Pie darba k̦ērās arī Latvijas likumdevēji, kas, sekojot ASV Prezidenta administrācijas ieteikumiem, pievērsās sasāpējušā nepilsoṇu jautājuma sakārtošanai. ${ }^{113}$ Rezultātā jau 15. aprīlì valdība bija apstiprinājusi rīcības plānu, kas paredzēja naturalizācijas logu atcelšanu.

Veiktie pasākumi pakāpeniski sāka dot cerēto efektu, un jau aprīḷa otrajā pusē krīzes atrisināšanā iesaistījās ASV: valsts sekretāre Madelēna Olbraita (Madeleine Albright) nosūtīja B. Jeḷcinam vēstuli ar brīdinājumu, ka pret Latviju ieviestās ekonomiskās sankcijas radīs negatīvas sekas. ${ }^{114}$ Īsā laika posmā Latvijai publisku atbalstu pauda arī citas ASV, Vācijas, EDSO un Baltijas jūras valstu padomes amatpersonas. ${ }^{115}$ Rietumvalstis pozitīvi vērtēja Latvijas valdības lēmumu reformēt arhaisko pilsonības likumu un aizvien stingrāk sāka nosodīt Krievijas ieviestās sankcijas.

Latvija beidzot guva pārliecību par Rietumu atbalstu un attiecībās ar Krieviju vairs nebija viena pati. Maskavai nebija izdevies izolēt Rīgu starptautiskajā arēnā, un Krievija bija spiesta atteikties no turpmāka tieša spiediena. Lai gan ekonomiskās sankcijas vēl kādu laiku palika spēkā, Latvijas un Krievijas attiecību krīzes izpausmes nākamajos mēnešos saruka līdz ierastajai negatīvajai retorikai.

Maskavas pozīciju mainu ietekmēja vairāki faktori.

- Pirmkārt, Krievija nespēja atrisināt samilzušo iekšpolitisko krīzi, kuras rezultātā 1998. gada 23. martā ar B. Jel̦cina ziņu tika atlaista V. Černomirdina valdība un Krievijas premjerministra pienākumu izpildīšana tika uzticēta uz ārpolitiku mazāk orientētajam Sergejam Kirijenko (Sergej Kirienko). ${ }^{116}$
- Otrkārt, Krievija turpināja slīgt aizvien dziḷākā ekonomikas krīzē. Vairākās nozarēs kavējās strādnieku algu izmaksa, un valstī draudēja izcelties iekšēji nemieri saistībā ar labklājības līmeṇa straujo krišanos. Maskavas lēmumu pieņēmējiem nācās secināt, ka Latvijas kā ārējā ienaidnieka tēls nav spējis novērst sabiedrības uzmanību no valsts iekšējām problēmām.

- Treškārt, Krievijas ieviestās ekonomiskās sankcijas kaitēja ne tikai Latvijas, bet arī pašas Krievijas jau tā nestabilajai ekonomikai un bija izraisījušas Rietumvalstu kritiku, kā rezultātā tika apdraudētas Maskavas starptautiskās pozīcijas.

Krievijas puse bija spiesta vismaz formālā līmenī atjaunot diplomātiskos sakarus ar Latviju. 23. aprīlī, piedaloties Latvijas ĀM valsts sekretāram Mārim Riekstinam un Krievijas ārlietu ministra vietniekam A. Avdejevam, Briselē notika pirmā abu pušu diplomātiskā tikšanās pēdējo divu mēnešu laikā. Latvijas un Krievijas attiecību krīze bija iegājusi nosacītā stabilitātes fāzē.

Tomēr iepriekšējo mēnešu pieredze lika domāt, ka Krievija varētu censties organizēt jaunas provokācijas gaidāmajos Uzvaras dienas pasākumos 9. maijā. Latvijas drošības iestādes bija mācījušās no iepriekš pieḷautajām kḷ̂udām un uz šo pasākumu laiku bija izstrādājušas īpašu darba režīmu, ${ }^{117}$ kā rezultātā 9. maija svinības notika bez liekiem incidentiem un tika aizvadìtas ierastajos toṇos - ar PSRS simboliku rotāti seniori turēja rokās A. Rubika un Josifa Stalina (Iosif Stalin) attēlus un periodiski izsauca saukḷus "fašismam - nē!" un "NATO - sliktāk nekā AIDS". ${ }^{118}$

14. maijā Rīgas centrā tika aizvadīta vēl viena Krievijas interesēm atbilstoša protesta akcija. Aptuveni 400-500 personas bija pulcējušās, lai paustu nepatiku pret Saeimas pienemto likumprojektu, kas 
paredzēja uzsākt pakāpenisku pāreju uz izglītību valsts valodā. Protesta akciju bija pieteikusi Latvijas Sociālistiskās partijas jauniešu nodaḷa, taču, kā mēḷja Latvijas prese, tās patiesie organizētāji slēpās nacionālboḷševiku rindās. Lai gan viens no radikāli noskan,otajiem krievu jauniešiem mītinā bija ieradies ar plakātu, kas vēstīja "nost ar latviešiem!", būtiskas provokācijas tā laikā izpalika. ${ }^{119}$

Latvijas ienemtais kurss uz stabilizāciju turpinājās arī starptautiskajā dimensijā. 1998. gada maijā M. Olbraita lika skaidri noprast, ka NATO vairs neņems vērā Krievijas intereses attiecībā uz Austrumeiropas valstu pievienošanos aliansei. ${ }^{120}$ Ar līdzīgu retoriku klajā nāca arī NATO runasvīrs Džimijs Šejs (Jimmy Shea), kurš apstiprināja, ka alianse turpinās savu paplašināšanās procesu un tas notiks "drīzāk agrāk, nekā vēlāk”, turklāt minot Latviju, Lietuvu un Igauniju kā potenciālās kandidātvalstis. ${ }^{121}$

Piekāpīgākās pozīcijās pret Maskavu joprojām atradās vecās Eiropas valstis, kuru ietekmes rezultātā ES noraidīja deklarāciju, kura rosināja nosodīt Krievijas sankcijas pret Latviju. ${ }^{122}$ Bija acīmredzams, ka Maskavas intereses Briselē joprojām lobēja Francija un Vācija, kas nevēlējās sabojāt attiecības ar Austrumu lielvalsti. ES nostāja attiecībā pret Krieviju sāka mainīties tikai jūlijā, kad Brisele bija spiesta atzìt, ka Maskavas pārmetumi Latvijai cilvēktiesību jomā ir bijuši nepamatoti.

Lai gan Maskava turpināja periodiski izteikt pārmetumus Latvijai, ar katru mēnesi pieaugošā ekonomiskā nestabilitāte traucēja tai saglabāt konsekventi augstu aktivitāti ārpolitikā. Vasaras izskaṇā ekonomiskā krīze, kas plosīja Krieviju, pakāpeniski tuvojās savam augstākajam punktam. Valstī strauji samazinājās Rietumu investīcijas, daudzās rūpniecības nozarēs apstājās algu izmaksas, reǵionos sāka parādīties spontānas pret režīmu vērstas protesta akcijas. Arī politiskajā līmenī Maskavā valdīja nestabilitāte. Krievijas VD bija klajā opozīcijā Kremlim, un Komunistiskā partija pieprasīja sākt prezidenta atstādināšanas procedūru. $^{123}$

Latvijas un Krievijas attiecību krīzei punktu pielika vasaras nogalē piedzīvotais Krievijas ekonomikas sabrukums. 17. augustā Maskava paziņoja, ka devalvē rubli, un bija spiesta lūgt Rietumvalstu ekonomisko palīdzību. Šādos apstākḷos Maskavai vienkārši nepietika finansējuma aktīvas ārpolitikas vešanai. ${ }^{124}$ Vēl jo vairāk, tā vairs nevarēja atḷauties riskēt sabojāt attiecības ar Rietumvalstīm, no kuru finansējuma bija atkarīga valsts tālākā nākotne. Maskavai neatlika nekas cits kā īslaicīgi pārtraukt lielāko dalu ārpolitisko afēru un koncentrēties uz samilzušo iekšējo problēmu risināšanu.

\section{Secinājumi}

Latvijas un Krievijas 1998. gada attiecību krīze ir uzskatāma par vienu no lielākajiem izaicinājumiem atjaunotās Latvijas vēsturē. Krīze satricināja Latvijas politisko eliti un sabiedrību, kā arī īslaicīgi radīja bažas par Latvijas eiroatlantiskās integrācijas procesa izdošanos. Par spīti pieredzētajām grūtībām, Latvijas puse no saspīlētās situācijas izgāja kā nosacìta uzvarētāja. Latvijas eiroatlantiskā integrācija netika būtiski traucēta, valstī saglabājās relatīva politiskā stabilitāte un etniskā konflikta iespējamība sevi pierādīja kā maz ticamu. Krievijas perspektīvā krīze nedeva cerētos rezultātus. Mākslīgi radītais Latvijas ārējā ienaidnieka tēls nebija pietiekams, lai novērstu sabiedrības uzmanību no straujā labklājības krituma. Vēl vairāk - Maskavas agresīvā ārpolitika iedragāja tās prestižu Rietumu partneru vidū.

Latvijas un Krievijas 1998. gada krīzes cēloṇus var nosacīti iedalīt vairākos virzienos. 
- Vēsturiski ideoloǵiskais virziens. Latvijas un Krievijas attiecības bija saspīlētas jau ilgi pirms 1997./1998. gada notikumiem. Abu pušu attiecību problemātikā centrālo lomu ieņēma atškirīga nostāja virknē aktuālu vēstures jautājumu, seviški saistībā ar Otro pasaules karu un padomju okupāciju. 20. gadsimta izskanāa šīs domstarpības kḷuva aizvien pamanāmākas un tika pastarpināti uzkurinātas ar Maskavas ziņu.

- Iekšpolitiskais virziens. Krievijas elitē bija nostiprinājies konservatīvs pasaules redzējums, kas uzstāja uz spēcīgu savas valsts interešu aizstāvēšanu. Maskavas tiešās interesēs bija izdarīt spiedienu uz kaimiņvalstīm, cerot gūt "diplomātisku uzvaru" uz brūkošās iekšpolitikas un ekonomikas fona. Savukārt Latvijā pie varas bija nākuši nacionālistiski noskaņoti politiķi, kuri nereti atklāti oponēja Krievijai un nerēķinājās ar tās interesēm.

- Sabiedriskais virziens. Latvijas sabiedrību raksturoja izteikta fragmentācija un vienotības trūkums. Galvenais šḳelšanās iemesls bija krievu minoritātes nespēja un/vai nevēlēšanās integrēties atjaunotajā Latvijas valstī. 1997./1998. gadā Latvijā aktualizējās virkne krievu kopienas vidū sevišķi jūtīgu jautājumu, piemēram, par nepilsoṇu statusu, leǵionāru piemiņas dienu, krievu valodas lietojumu un pāreju uz mācībām valsts valodā. Latvijas valdībai nelojālā krievu kopiena bija galvenais Maskavas instruments krīzes laikā.

- Ekonomiskais virziens. Pirmskrīzes un krīzes periodā Krievija saskārās ar vērā ṇemamu ekonomisko nestabilitāti, kā rezultātā strauji kritās iedzīvotāju ienākumu līmenis. Lai novērstu sabiedrības uzmanību no brūkošās ekonomikas,
Maskavai bija nepieciešams aktualizēt ārējā ienaidnieka tēlu, par kuru bija lemts kḷūt Latvijai. Vēl jo vairāk, pirmskrīzes periodā Latvijas valdība bija likusi noprast, ka tās plānos ietilpst Maskavas ekonomiskās ietekmes mazināšana, kas raisīja nepatiku Krievijas biznesa aprindās.

- Starptautiskais virziens. Pirmskrīzes periodā Maskavas lēmumu pieņēmēji bija satraukti par Vašingtonas un NATO aizvien uzstājīgāko tuvināšanos ar Baltijas valstīm. N̦emot vērā, ka Kremḷa gaiteņos bija nostiprinājušies pretrietumnieciski orientētie politiki, Maskava lēma par labu tam, lai pēc iespējas kavētu baltiešu eiroatlantiskās integrācijas procesu, destabilizējot situāciju Latvijā.

Lai gan publicētajos avotos nav pieejami tieši pierādījumi par to, ka aiz 1998. gada pavasarī pieredzētajām protesta akcijām un spridzināšanām stāvēja Krievija, var pieḷaut, ka vismaz pastarpināti tās varēja tikt īstenotas ar Maskavas ziņu. Krievijas rīcībā bija virkne ietekmes instrumentu, ar kuru palīdzību tā 1998. gada pavasarī varēja izdarīt spiedienu pret Latviju:

- Kremlim pietuvinātie oligarhi noderēja kā instruments, lai ieviestu pret Latviju vērstas ekonomiskās sankcijas, kā arī îstenotu propagandas kampaṇu to kontrolē esošajos medijos;

- Kremlim lojālās nevalstiskās organizācijas tika izmantotas, lai izplatītu dezinformāciju un diskreditētu Latviju starptautiskajā vidē;

- Maskavai lojālā krievu kopiena tika konsolidēta protesta akciju organizēšanai;

- Latvijā un Krievijā mītošie politiskie radikāḷi varēja tikt izmantoti dažādu provokāciju veikšanai. 


\section{ATSAUCES UN SKAIDROJUMI}

${ }^{1}$ ZANETA OzolinA. Crisis Prevention or Intervention: Latvia's Response to the Proposed Russian Security Guarantees. In: ERIC STERN, DAN HANSEN (eds.). Crisis Management in a Transitional Society. Stockholm 1999, p. 199.

2 Šajā periodā Latvija aktīvi iesaistījās NATO programmā "Partnerattiecības mieram", un Latvijas bruñotie spēki kopš 1996. gada piedalījās alianses operācijā Bosnijā un Hercegovinā.

${ }^{3}$ Aivars StrangA. The Relations Between Russia and the Baltic States: 1997-1998. Jahrbuch für internationale Sicherheitspolitik. Berlin 1999, p. 138.

${ }^{4}$ INESIS FELDMANIS, JĀNIS TAURĒNS. Latvijas ārpolitika un diplomātija 20. gadsimtā. 3. sēj. Rīga 2016, 116. lpp.

${ }^{5}$ Ibidem, 118. lpp.

${ }^{6}$ STRANGA, The Relations Between Russia and the Baltic States, pp. 138-139.

${ }^{7}$ Ibidem.

${ }^{8}$ Ibidem, p. 140.

${ }^{9}$ Madrid Declaration on Euro-Atlantic Security and Cooperation, 1997. Pieejams: https://www. NATO.int/docu/pr/1997/p97-081e.htm (skatīts 25.05.2018.).

${ }^{10}$ Against the Baltic's NATO bid. In: The Baltic Times, 11.-17.09.1997., p. 2.

${ }^{11}$ JĀNIS ŪDRIS. Šodien Viḷnā - Austrumeiropas valstu samits. In: Latvijas Vēstnesis, 05.09.1997. Pieejams: https://www.vestnesis.lv/ta/id/44771 (skatìts 24.05.2018.).

12 Ozolina, Crisis Prevention or Intervention, p. 194.

${ }^{13}$ Deklarācija par Ministru kabineta iecerēto darbību, 1997. Pieejams: https://mk.gov.lv/sites/ default/files/editor/krasts_deklaracija.pdf (skatīts 26.05.2018.).

${ }^{14}$ Alla PetropavlovsKaJA. Guntars Krasts: Ja verju v sebja. In: SM, 17.09.1997., s. 2.

${ }^{15}$ ĀRIS JANSONS. Pārmaiņas Kremlī. In: Diena, 23.09.1997., 2. lpp.

16 ÂRIS JANSONS. G̦eopolitikas ēna Krievijas prioritāšu meklējumos. In: Diena, 03.10.1997., 2. lpp.

${ }^{17}$ Pie Valsts prezidenta - Amerikas Savienoto Valstu politiḳis - Krievijas Federācijas vēstnieks. In: Latvijas Vēstnesis, 28.10.1997. Pieejams: https://www.vestnesis.lv/ta/id/30833 (skatīts 29.05.2018.).

${ }^{18}$ ANITA SMOḶENSKA. Būs viena ASV un Baltijas valstu harta. In: Diena, 15.10.1997., 1. lpp.

${ }^{19}$ Krievija, iespējams, cerēja uz Lietuvas atbalstu, ar kuru pirms drošības garantiju piedāvāšanas tika sekmīgi noslēgts robežlīgums.

${ }^{20}$ Stranga, The Relations Between Russia and the Baltic States, p. 142.

${ }^{21}$ Ozolina, Crisis Prevention or Intervention, p. 195.

${ }^{22}$ Aivars STRANGA. Baltic - Russian Relations 1998-99. In: ATIS LeJINS (ed.). Baltic Security Prospects at the Turn of $21^{\text {st }}$ Century. Helsinki 1999, p. 127.

${ }^{23}$ JURIS TiHonovs. Nesteidz ar atbildi Kremlim. In: Diena, 30.10.1997., 1. 1pp.

${ }^{24}$ STRANGA, The Relations Between Russia and the Baltic States, p. 141.

${ }^{25}$ Ozolina, Crisis Prevention or Intervention, p. 202.

${ }^{26}$ ROKAS TRACEVSKIS. Lithuania and Estonia reject Russian security guarantees. In: The Baltic Times, 06.-12.11.1997., p. 1.

${ }^{27}$ Ozolina, Crisis Prevention or Intervention, p. 197.

${ }^{28}$ Kto tam krassnij kommisar? In: SM, 06.11.1997., s. 2.

${ }^{29}$ JĀNIS LAUVA. Krievijā turpinās ažiotāža ap drošības garantijām. In: Neatkarīgā Rīta Avīze, 13.11.1997., 6. lpp.

${ }^{30}$ NELLIJA LOČMELE. Jeḷcins aicina veidot “uzticības režīmu” Baltijas reǵionā. In: Diena, 04.12.1997., 1. lpp.

${ }^{31}$ NeLliJA LoČMELE. Jeḷcins par Baltiju. In: Diena, 04.12.1997., 3. lpp.

32 PĀVels Širovs. Vai pēdējais Krievijas reformators? In: Diena, 24.11.1997., 4. 1pp. 
${ }^{33}$ Kremlis noliedz Jeḷcina saslimšanas saistību ar sirds problēmām. In: Diena, 12.12.1997., 9. lpp.

${ }^{34}$ PĀVELS ŠIrovs. Jaunais gads Krievijā nāk ar rubḷa denomināciju. In: Diena, 29.12.1997., 5. lpp.

${ }^{35}$ Konstantin KAZAKOv. Latvija poluchila priglashenie vtorogo sorta. In: Chas, 15.12.1997., s. 4.

${ }^{36}$ Partnerības harta starp Latvijas Republiku, Igaunijas Republiku, Lietuvas Republiku un Amerikas Savienotajām Valstīm. Pieejams: https://m.likumi.lv/doc.php?id=31233 (skatîts 09.06.2018.).

${ }^{37}$ Stranga, The Relations Between Russia and the Baltic States, p. 143.

${ }^{38}$ PĀVELS ŠIrovs. Krievija: harta ir drauds Eiropas drošībai. In: Diena, 21.01.1998., 1. lpp.

39 JURIS Tihonovs. Krievijas ĀM: PSRS neokupēja Baltijas valstis. In: Diena, 20.01.1998., 1. lpp.

40 JuRIS TiHonovs. Latvija atbildēšot Vizentāla centram. In: Diena, 21.01.1998., 1. lpp.

${ }^{41}$ DACE Plato. Krievu kultūras biedrības sūdzas Černomirdinam. In: Diena, 22.01.1998., 2. lpp.

${ }^{42}$ AIgARS ŠTĀLS, JuRIS TiHONOvS. Maskavas sociologi Latvijā pēta sabiedrības noskaņojumu. In: Diena, 19.01.1998., 4. lpp.

43 JuRIs Tihonovs. Krievijas sociologi bāzējušies fondā Drošība. In: Diena, 29.01.1998., 1. lpp.

${ }^{44}$ GunTIS ENIN̦Š. Latvijas Republikas 6. Saeimas ziemas sesijas piektā sēde, 12.11.1998. Pieejams: http://www.saeima.lv/steno/st_98/st1202.html (skatīts 10.06.2018.).

${ }^{45}$ Mitchell LANDSBerg. Yeltsin: Clinton risks World War III in Iraq. In: The Baltic Times, 12.-18.02.1998., p. 2.

${ }^{46}$ TANYA Neuman. Baltics offer help in Iraqi crisis. In: The Baltic Times, 26.02.1998., p. 1.

${ }^{47}$ INNA HARLANOva. Za poteri pust' platit vinovnyj. In: Panorama Latvii, 01.03.1998., s. 1.

${ }^{48}$ DitA ARĀJA, Edgars GAlzons. Piketētāji Valdemāra ielā bloḳē satiksmi. In: Diena, 04.03.1998., 3. lpp.

${ }^{49}$ Tracis pie Rīgas Domes. In: Neatkarīgā Rīta Avīze, 04.03.1998., 2. lpp.

${ }^{50}$ Aivars Stranga. The End Product: A Crisis in Latvian-Russian Relations. NATO 1999, p. 3.

${ }^{51}$ PĀVELS ŠIrovs, JuRIS TiHONOVs. Krievijas ĀM aicina pasaules sabiedrību nosodīt akciju Rīgā. In: Diena, 05.03.1998., 1.-3. lpp.

${ }^{52}$ STRANGA, Baltic - Russian Relations 1998-99, p. 130.

${ }^{53}$ SARMA KoČĀNE, INTA LASE. Krievija pel, policiju Latvijā. In: Diena, 05.03.1998., 1. lpp.

${ }^{54}$ Skandal'naja Slava. In: Chas, 06.03.1998., s. 2.

${ }^{55}$ EviJA OzolA. Krievijas nosodījums kḷūst aizvien skaḷāks. In: Neatkarīgā Rīta Avīze, 07.03.1998., 2. lpp.

${ }^{56}$ EviJA OzolA. Rīgas mītiņš izraisa plašu rezonansi. In: Neatkarīgā Rīta Avīze, 06.03.1998., 2. lpp.

57 ŠIrovs, TiHonovs, Krievijas ĀM aicina pasaules sabiedrību nosodīt akciju Rīgā, 1.-3. lpp.

${ }^{58}$ PĀVels ŠIrovs, JuRIS Tihonovs. Atceḷ Krievijas Valsts domes spīkera vizīti Latvijā. In: Diena, 07.03.1998., 1.-3. lpp.

${ }^{59}$ PĀVELS ŠIROVs, JURIS TiHONOvs. Krievija apsver sankcijas pret Latviju. In: Diena, 09.03.1998., 1. lpp.

${ }^{60}$ ABIK JELKIN. Sankcii Budut! In: SM, 10.03.1998., s. 1.

${ }^{61}$ STRANGA, Baltic - Russian Relations 1998-99, p. 133.

62 ŠIrovs, TiHONOvs, Krievijas ĀM aicina pasaules sabiedrību nosodīt akciju Rīgā, 1.-3. lpp.

${ }^{63}$ ŠIrovs, TiHonovs, Atcel Krievijas Valsts domes spīkera vizìti Latvijā, 1.-3. lpp.

${ }^{64}$ Nellija LoČMele, Baiba Rulle. Vēstniekam skaidro pie Rīgas domes notikušo. In: Diena, 10.03.1998., 1. lpp.

${ }^{65}$ EviJA OzolA. 3. marta pikets - vai provokācija. In: Neatkarīgā Rīta Avīze, 12.03.1998., 5. lpp.

${ }^{66}$ INGA PAPARDE. Tiesa atbrīvo Rubiku. In: Neatkarīgā Rīta Avīze, 07.11.1997., 1. lpp.

${ }^{67}$ JĀNIS BRŪKLENIS, AIVARS PASTALNIEKS. Neskaidrības ap Rubika atbrīvošanu. In: Neatkarīgā Rīta Avīze, 07.11.1997., 1. lpp.

${ }^{68}$ StrangA, The Relations Between Russia and the Baltic States, p. 146. 
${ }^{69}$ STRAnga, The End Product, p. 5.

${ }^{70}$ PĀvels ŠIrovs. Lužkovs Latviju salīdzina ar Kambodžu. Diena, 28.03.1998., 1. lpp.

${ }^{71}$ STRANGA, Baltic - Russian Relations 1998-99, p. 131.

${ }^{72}$ SANDRIS METUZĀLS. Latvijā pabijis krievu fašistu līderis? In: Neatkarīgā Rīta Avīze, 30.10.1997., 1. lpp.

${ }^{73}$ V. STREL'Cov. Rizhskie Vervol'fovichy. In: SM, 05.10.1997., s. 3.

${ }^{74}$ DACE Plato. Krievu diasporas apvienošanai Latvijā dibina jaunu organizāciju. In: Diena, 10.10.1997., 4. lpp.

${ }^{75}$ JURIS TiHONOvs. Pasaules prese turpina ziņot par leǵionāriem un nepilsoṇiem. In: Diena, 21.03.1998., 4. lpp.

${ }^{76}$ Evita Prokopova, Juris Tihonovs. Troksnis ap latviešu leğionāru svinībām. In: Diena, 04.03.1998., 3. lpp.

77 Daina Bleiere, Aivars Stranga. The Latvian Russian Crisis of 1998. In: Stern, Hansen, Crisis Management in a Transitional Society, p. 223.

78 Šogad leǵionu piemin saspringtā gaisotnē. In: Diena, 17.03.1998., 3. lpp.

${ }^{79}$ Bleiere, Stranga, The Latvian Russian Crisis of 1998, pp. 236-237.

${ }^{80}$ Vchera oni opozorili nashu stranu. In: Chas, 17.03.1998., s. 1.

${ }^{81}$ ULDIS NEIBURGS. SS, Waffen SS, latviešu leǵions un Latvijas valsts politika. In: Diena, 06.03.1998., 2. lpp.

82 Bleiere, Stranga, The Latvian Russian Crisis of 1998, p. 239.

83 Ibidem.

${ }^{84}$ Latvian Legion fallout: Kohl, Chirac condemn march. In: The Baltic Times, 02.-08.03.1998., p. 8.

${ }^{85}$ JuRIS TiHonovs. Latvijas vēstniecību apmētā ar olām. In: Diena, 17.03.1998., 1. lpp.

${ }^{86}$ BleiERE, Stranga, The Latvian Russian Crisis of 1998, p. 241.

${ }^{87}$ NATAL'JA LeBedEVA. Russkaja atmoda. In: SM, 18.03.1998., s. 1.

${ }^{88}$ Evita Prokopova, JuRis Tihonovs. Prasa pagarināt pasu derīgumu. In: Diena, 18.03.1998., 1.-3. lpp.

${ }^{89}$ Evita ProKopova. PĀVELS Širovs. Krievijas nacionālboľ̦̌eviki "izgaismojas" Latvijā. In: Diena, 20.03.1998., 4. lpp.

${ }^{90}$ Skolas apgānītāji aizturēti. In: Lauku Avīze, 14.03.1998., 3. lpp.

${ }^{91}$ JĀNIS VANAGS. Piketā aicina uz cīṇu nemaksājot rēḳinus. In: Diena, 17.03.1998., 1. lpp.

${ }^{92}$ MĀRIS Puk̦ītis. Revolucionārajai pagrīdei sava avīze. In: Lauku Avīze, 31.03.1998., 4. lpp.

${ }^{93}$ NATAL'JA LebedeVA. V kazhdom russkom v Latvii vidjat Stalina. In: SM, 26.03.1998., s. 1.

${ }^{94}$ Konstantin KazAKov, AleKSANDR Shunin. Den' neistovoj rusofobii. In: Chas, 26.03.1998., s. 2.

${ }^{95}$ EDGARS GALZONS. Iesper piemiņas brǐža dalībniecei. In: Diena, 26.03.1998., 8. lpp.

${ }^{96}$ Pirms tam sprādzieni bija notikuši 1995. gada pavasarī un 1997. gada nogalē.

${ }^{97}$ WiLl ENGLUND. Crimes of nazis and communists haunt Latvia bitter recriminations rooted in 1940s strain Moscow-Riga relations. In: Baltimore Sun, 05.04.1998. Pieejams: http://articles. baltimoresun.com/1998-04-05/news/1998095051_1_latvian-legion-russian-communism-russianminority (skatīts 19.06.2018.).

${ }^{98}$ Bleiere, Stranga, The Latvian Russian Crisis of 1998, p. 242.

${ }^{99}$ AleKsej Stefanov. FBR nachinaet rassledovanie. In: Chas, 06.04.1998., s. 2.

${ }^{100}$ Latvian police chief sacked over Riga synagogue bombing. In: BBC News, 02.04.1998. Pieejams: http://news.bbc.co.uk/2/hi/europe/72900.stm (skatīts 07.05.2018.).

${ }^{101}$ Bleiere, Stranga, The Latvian Russian Crisis of 1998, p. 242.

${ }^{102}$ Ibidem, p. 243. 
${ }^{103}$ Konstantin Kazakov, Aleksej Stefanov. Bomba: pod Rossiju? pod Latviju? In: Chas, 07.04.1998., s. 2.

${ }^{104}$ ALEKSANDR KRASNITSKIJ. Obraz Latvii. In: Chas, 07.04.1998., s. 1.

105 Bleiere, Stranga, The Latvian Russian Crisis of 1998, p. 241.

${ }^{106}$ SERGEJ BARDOvSKIJ. Riga zhdjot diversij. In: Chas, 14.03.1998., s. 2.

107 Aleksej Stefanov. Liepaja: Koshhunstvo na kladbishhe. In: Chas, 06.04.1998., s. 1.

${ }^{108}$ ANDREJ PORTnOV, VITA SHTEJN. Terakt, eshhjo terakt. In: SM, 07.04.1998., s. 1.

${ }^{109}$ Nas utro vstrechaet svastikoj. In: SM, 08.04.1998., s. 1.

${ }^{110}$ AleKSEJ Stefanov. Vzryv v Rezekne ne sostojalsja. In: Chas, 14.04.1998., s. 2.

${ }^{111}$ Bleiere, Stranga, The Latvian Russian Crisis of 1998, p. 228.

112 Ibidem.

${ }^{113}$ Ibidem.

${ }^{114}$ STEVEN ERLANGER. U.S. is trying to defuse a growing Russia-Latvia confrontation. In: The New York Times, 16.04.1998. Pieejams: https://www.nytimes.com/1998/04/16/world/us-is-trying-todefuse-a-growing-russia-latvia-confrontation.html (skatîts 20.06.2018.).

115 Bleiere, Stranga, The Latvian Russian Crisis of 1998, p. 228.

116 PĀVELS Širovs. Krievijā sastāda jaunu valdību. In: Diena, 24.03.1998., 1. lpp.

117 Bleiere, Stranga, The Latvian Russian Crisis of 1998, p. 253.

${ }^{118}$ DitA ARĀJA. Pārdaugavā svin Lielā Tēvijas kara beigu gadadienu. In: Diena, 11.05.1998., 4. lpp.

119 GunitA NAGLE, JuRIS TiHONOvs. Nacionālboḷševiki saliedē izglītības likumprojekta kritizētājus. In: Diena, 15.05.1998., 1.-4. lpp.

${ }^{120}$ Madelēna Olbraita. Pietiek satraukties par Krieviju. In: Diena, 05.05.1998., 2. lpp.

${ }^{121}$ KRISTĪNE PlAMŠE. NATO paplašināšana turpināšoties. In: Diena, 07.05.1998., 1. 1pp.

${ }^{122}$ KRISTĪNE PlAMŠE. ES runās ar Latviju un Krieviju. In: Diena, 06.05.1998., 1. lpp.

${ }^{123}$ FELdMAnIS, TAURĒNS, Latvijas ārpolitika un diplomātija 20. gadsimtā, 141. lpp.

${ }^{124}$ Konstantin Voronov. The Baltic Policy of New Russia: A Brief History of the Stormy Decade. In: TALAVs JunDZIS (ed.). The Baltic States at Historical Crossroads. Riga 2001, p. 500.

\section{SUMMARY}

The first signs of the growing crisis in Latvian-Russian relations were established already in early 1997. Russian foreign affairs of that time already showed that Kremlin has started work on development of new strategy regarding the Baltic states. In March 1997, during the US-Russian summit in Helsinki, Russian President Boris Yeltsin for the first time publicly announced that Russia would be ready to give security guarantees to the Baltics. During the next few months, the Russian political elite gradually secured the anti-Western sentiment and concerns about NATO enlargement process in post-Soviet space. Eventually, Moscow decided to increase pressure against the Baltic states in order to hamper the newly commenced Euro-Atlantic integration process.

In autumn 1997, Russian officials once more came out publicly with the idea of providing security guarantees to the Baltic states. In late October 1997, all three Baltic sister nations received an official draft project of security guarantees from the Russian Federation. It is highly unlikely that Moscow ever really hoped that the Baltic states would actually accept such proposal. Most likely, the main reason behind promises of security guarantees was the Russian intention to test the reaction of the West and discredit solidarity of the Baltic states. To a certain extent Moscow achieved its goals, 
since the Western countries were too inert regarding the idea of supporting the Baltic nations, meanwhile, indolence of Baltic politicians (especially of the Latvian ones) created the impression that Baltic states were too weak and unable to make proper decisions in crisis situation.

In late 1997, due to growing domestic problems, Russian foreign affairs activities regarding the Baltics slightly abated. Nevertheless, because of the straight course taken by the Baltics towards NATO and further Euro-Atlantic integration, the issue was put on Russian decision makers' agenda again. Kremlin reacted especially harshly to the charter of partnership among the USA and the Baltic states signed in the early 1998, and the support expressed by the Baltics to the Washington regarding the crisis in Iraq.

In comparison to other Baltic states, Latvia had the worst relations with Russia during that period of time. From the Moscow's perspective, power in Latvia was taken over by the nationalists who dared to object to Russian interests in international affairs and ignored the rights of the Russian minority residing in Latvia. The protest of pensioners by the Riga Council building on 3 March 1998 dispersed by the Latvian law-enforcement institutions exacerbated the crisis between both states. Already on the next day, the Kremlin launched a defamation campaign against Latvia to discredit it at international level and put in action unofficial economic sanctions.

In addition, the annual march of Waffen SS legionaries, which took place on 16 March in Latvia with participation of some state officials was also used by the Kremlin to discredit Latvia internationally. However, the Western countries avoided to publicly announce unconsidered decisions regarding the ongoing developments in Latvia. Furthermore, activities demonstrating Kremlin's influence did not result in any effect on domestic affairs of Latvia. Despite some protests, the overall situation within the country remained peaceful.

In April 1998, two IEDs exploded near the Riga Synagogue and the Russian Embassy. Russia attempted to use the explosions to destabilize the situation in Latvia. The Latvian officials, bearing in mind the previously made mistakes, successfully managed to avert the potential escalation of the crisis. In addition, during this period of time Latvia was able to retain a relative political stability. Eventually, Latvian political decision makers started to pay more attention to developing the state's foreign policy in order to explain the Western counterparts the delicate relations between Latvia and the Kremlin at the time.

In late spring and summer of 1998, the West finally provided Latvia with the urgently needed support by expressing criticism of Russia even more frequently, for the Kremlin had artificially created the crisis in relations between Latvia and the Russian Federation. Meanwhile, the economic situation in Russia continued to decline; eventually, on 17 August 1998 Moscow was forced to devalue the Russian rouble. In the advent of the economic crisis, the issue of Latvia disappeared from Kremlin's foreign policy agenda and the relations between both states gradually became stable. 